\title{
INTERGRANULAR CORROSION AND DUCTILE-BRITTLE TRANSITION BEHAVIOUR IN MARTENSITIC STAINLESS STEEL
}

\author{
GunAwan, Amir Arifin* \\ Department of Mechanical Engineering, Faculty of Engineering, Universitas Sriwijaya, Indralaya, \\ 30662, Sumatera Selatan, Indonesia \\ *Corresponding author: amir@unsri.ac.id
}

(Received: 8 August 2021; Accepted: 21 September 2021; Published on-line: 1 November 2021)

\begin{abstract}
Material mechanical behavior is critical for both safety and economic considerations. Because engineering items are manufactured using appropriate grade materials, mechanical approval of the materials used must be completed before assembly. Petrochemicals, marine, and biomaterials are just a few of the industries that use stainless steel. Despite its extensive use, structural failure is still frequently caused by inadequate stainless steel type selection. As a result, dangerous conditions, resulting in personal harm or financial loss. Dangerous conditions is might result in accidents, resulting in personal injury or financial loss. Martensite stainless steel is a type of stainless steel with a high strength value but is brittle, necessitating careful handling. Intergranular corrosion, sensitization, tempering heat treatment, and the Ductile to Brittle Transition Temperature (DBTT) are topics still working on Martensite stainless steel for researchers.
\end{abstract}

KEY WORDS: Martensitic Stainless Steel, Intergranular Corrosion, and Ductile-Brittle Transition

\section{INTRODUCTION}

The main alloying element that makes stainless steel "stainless" is chromium. The protective chrome oxide film that provides corrosion resistance and a gleaming, silvery look requires more than 10.5 percent chromium in steel $[1,2]$. At this chromium level, a chromiumenriched surface oxide called the passive layer, or passive film, formed the steel. It protects the stainless steel. Stainless steels come in various shapes and sizes, but they all comply with the chromium requirement. Austenitic, ferritic, duplex (mixed ferritic and austenitic), and martensitic are the four types of stainless steel [1,3]. Fig. 1 shows that martensitic stainless steel has a higher strength than other types of stainless steel. However, martensitic stainless steel tends to be brittle and has low toughness compared to different types of stainless steel.

Martensitic stainless steels are utilized because of their excellent corrosion resistance. Commercial $13 \% \mathrm{Cr}$ steel with more than $0.08 \% \mathrm{C}$ is the most often used martensitic stainless steel. Fig. 2 shows the phase diagram of the vertical section of the $\mathrm{Fe}-\mathrm{Cr}-\mathrm{C}$ at $13 \% \mathrm{Cr}$. 


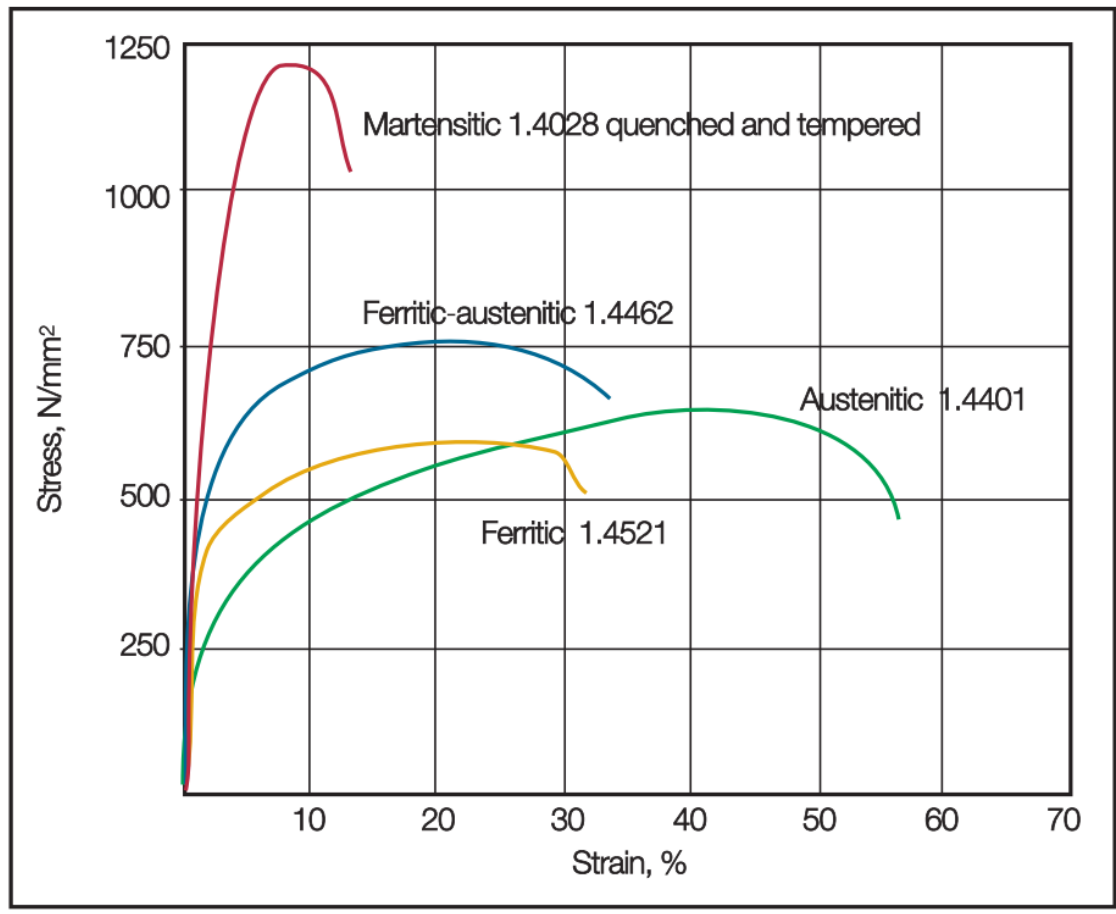

Fig. 1. Stress-strain curves of four different types of stainless steel [4].

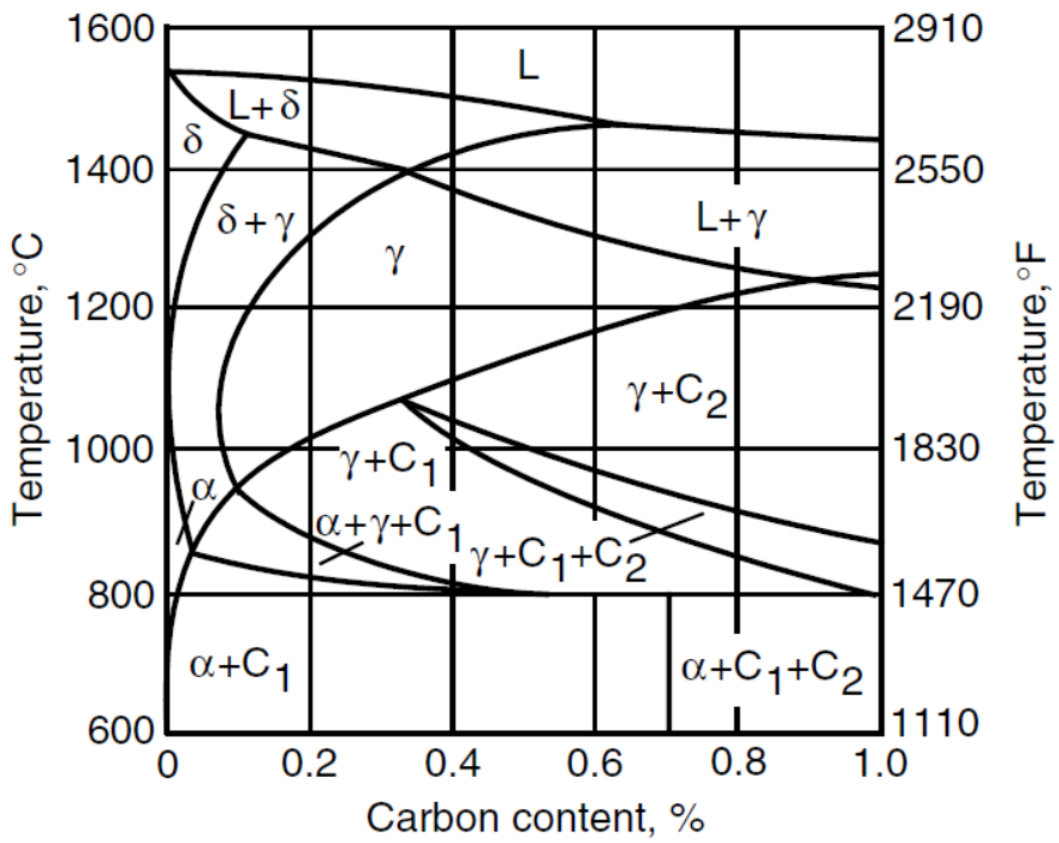

Fig. 2. Vertical section of $\mathrm{Fe}-\mathrm{Cr}-\mathrm{C}$ phase diagram at $13 \% \mathrm{Cr}[5]$

Martensitic stainless steels are iron-based alloys with 11.5-18 wt\% chromium and 0.1-1.2 wt\% carbon (i.e., higher than other grades of stainless steels), which are widely utilized in various sectors due to their excellent mechanical strength and corrosion resistance[6]. High strength is desired in applications such as cutlery and surgical devices [7-9], but toughness and flexibility are unimportant. A lower temperature tempering is used to sustain the material's tensile strength. A typical composition for such applications is type 420 steel $(0.15-0.4 \mathrm{C}$, 
1.0Mn, 1.0Si, $0.04 \mathrm{P}, 0.03 \mathrm{~S}, 12-14 \mathrm{Cr} w \mathrm{t} \%)$. The chemical content of various traditional martensitic grades is shown in Table 1. AISI 410 and AISI 420, with chromium contents averaging $12 \mathrm{wt} \% \mathrm{Cr}$, are the most widely used.

Table 1. Chemical composition (\% wt.) of some grades of martensitic stainless steels [10]

\begin{tabular}{|l|l|l|l|l|l|l|l|l|}
\hline Usual name & UNS & $\% \mathrm{C}$ & $\% \mathrm{Cr}$ & $\% \mathrm{Mo}$ & $\% \mathrm{Ni}$ & $\begin{array}{l}\% \mathrm{Mn} \\
(\max .)\end{array}$ & $\begin{array}{l}\% \mathrm{Si} \\
(\max )\end{array}$ & Other \\
\hline AISI 410 & $\mathrm{S} 41000$ & 0.15 & $11.5-13.5$ & - & 0.75 máx. & 1.0 & 1.0 & -- \\
\hline AISI 420 & $\mathrm{S} 42000$ & 0.15 min. & $12.0-14.0$ & - & - & 1.0 & 1.0 & - \\
\hline AISI 431 & $\mathrm{S} 43100$ & 0.20 max. & $15.0-17.0$ & - & $1.25-2.5$ & 1.0 & 1.0 & - \\
\hline AISI 440A & $\mathrm{S} 44002$ & $0.60-0.75$ & $16.0-18.0$ & 0.75 & - & 1.0 & & - \\
\hline AISI 440B & S44003 & $0.75-0.90$ & $16.0-18.0$ & 0.75 & - & 1.0 & 1.0 & - \\
\hline AISI 440C & S44004 & $0.90-1.20$ & $16.0-18.0$ & 0.75 & - & 1.0 & 1.0 & - \\
\hline 17-4PH & S17400 & 0.07 max. & $15.0-17.5$ & - & $3.0-5.0$ & 1.0 & 1.0 & $3.0-5.0 \% \mathrm{Cu}$ \\
\hline CA6NM & J91540 & 0.06 max. & $11.5-14.0$ & $0.4-1.0$ & $3.5-4.5$ & 1.0 & 1.0 & - \\
\hline
\end{tabular}

A martensitic phase in martensitic stainless steel is produced through austenitizing heat treatment at 970-1100. The austenitizing process makes a body-centered tetragonal crystal structure [11, 12]. Unfortunately, this tempering has the potential to affect corrosion susceptibility. When type 420 stainless steel is tempered at temperatures between $450^{\circ}$ and $600^{\circ} \mathrm{C}$, for example, its corrosion susceptibility is at its peak. The mechanical and physical properties of martensitic stainless steels are magnetic, exceedingly strong, highly machinable. The martensitic stainless steel can be toughened by heat treatment, despite not being as corrosion-resistant as the 200 and 300 classes. The tempering steels at 200 to $700^{\circ} \mathrm{C}$ results in the formation of chromium carbides and the relaxation of the martensitic matrix. This condition is resulting in a better balance of strength and ductility. The purpose of this research is to explore several martensite stainless steel concerns.

\section{INTERGRANULAR CORROSION}

Intergranular corrosion is a potential degrading issue for Martensitic stainless steel. Martensitic stainless steel is always in tempered conditions due to the precipitation of chromium-rich carbides. The precipitation precedes austenitic grain boundaries and at the martensitic lath borders [6, 13-16]. Chromium will decrease in the metal matrix around the carbide, resulting in chromium depletion at the carbide-matrix interface. Sensitization, a state of local chromium depletion that results in carbides precipitating, promotes intergranular corrosion, as shown in Fig. 1. It is an unfavorable outcome of hasty heat treatment or welding. The majority of papers on intergranular corrosion deal with austenitic steels. Fig. 3 shows Intergranular corrosion AISI 410 stainless-steel piston rod in spillway floodgate.

Intergranular corrosion and passive layer performance are potential issues in martensitic steels. Intergranular corrosion and passive layer performance are always used in tempered conditions, encouraging carbide formation. The tempered martensite microstructure of normalized-and-tempered martensitic steels is more complicated than a solid solution, as shown in Fig. 4. The steel is heated above the $\mathrm{AC}_{3}$ temperature during the normalization procedure to convert the ferrite for a solid solution of austenite, which cools to body-centred tetragonal (BCT) martensite. Martensite microstructure can be shown in Fig. 5. During the tempering treatment below the $\mathrm{AC}_{1}$ temperature, the Bmartensite transforms to a bcc ferrite matrix with the accompanying precipitation of $\mathrm{M}_{23} \mathrm{C}_{6}$. $\mathrm{M}$ is $\mathrm{Cr}$ rich with small amounts of $\mathrm{Fe}$, $\mathrm{Mn}, \mathrm{Mo}, \mathrm{W}$, etc., and MX. M is Nb- and $\mathrm{V}$-rich, depending on composition, with small amounts of $\mathrm{Fe}, \mathrm{Cr}$, Mo, etc., and $\mathrm{X}$ are $\mathrm{C}$ and $\mathrm{N}$. Tempered martensite microstructure is a ferrite solid 
solution matrix containing a high number density of the carbide precipitates primarily on subgrain boundaries (former martensite lath and packet boundaries) and prior-austenite grain boundaries.

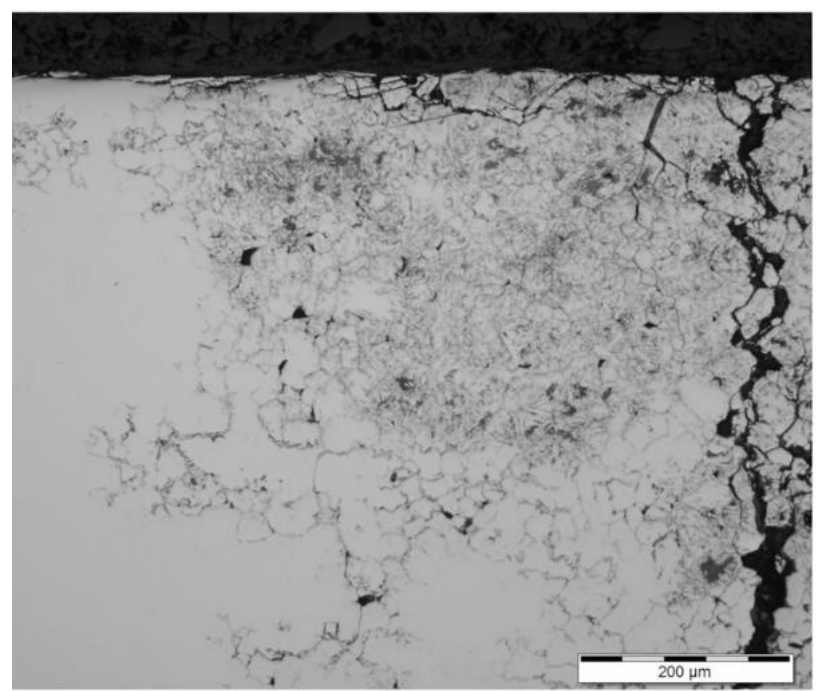

Fig. 3. Intergranular corrosion on AISI 410 stainless-steel[17]

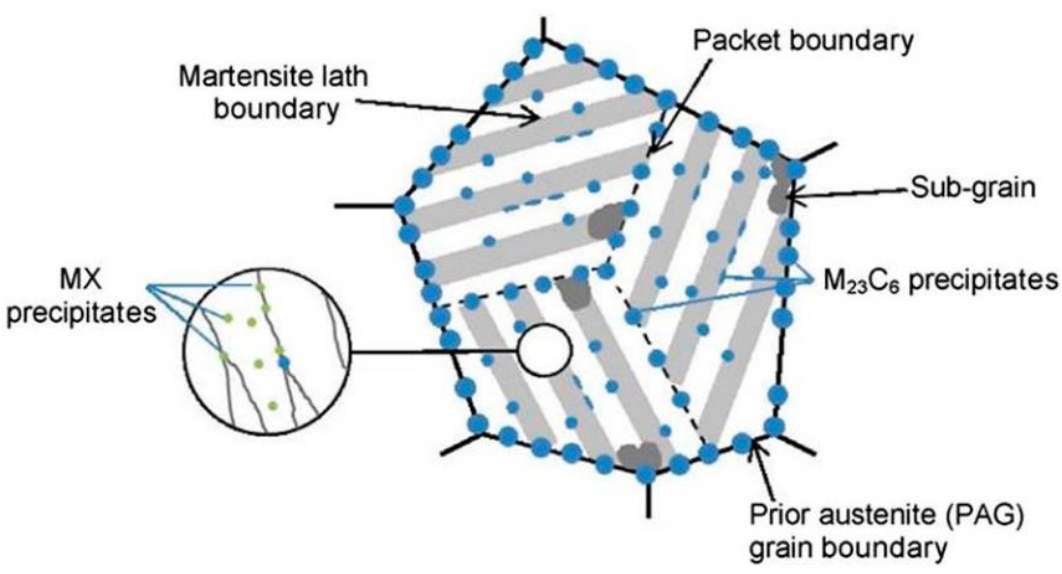

Fig. 4. Tempered martensite: Carbides on grain boundaries, sub-grain boundaries, and ferrite matrix [18]

The temperature at which a material transitions from ductile to brittle or brittle to ductile is called the 'Ductile to Brittle Transition Temperature (DBTT). The ductile to brittle transition temperature is strongly dependant on the composition of the metal. Steel is the most commonly used metal that shows this behaviour. 


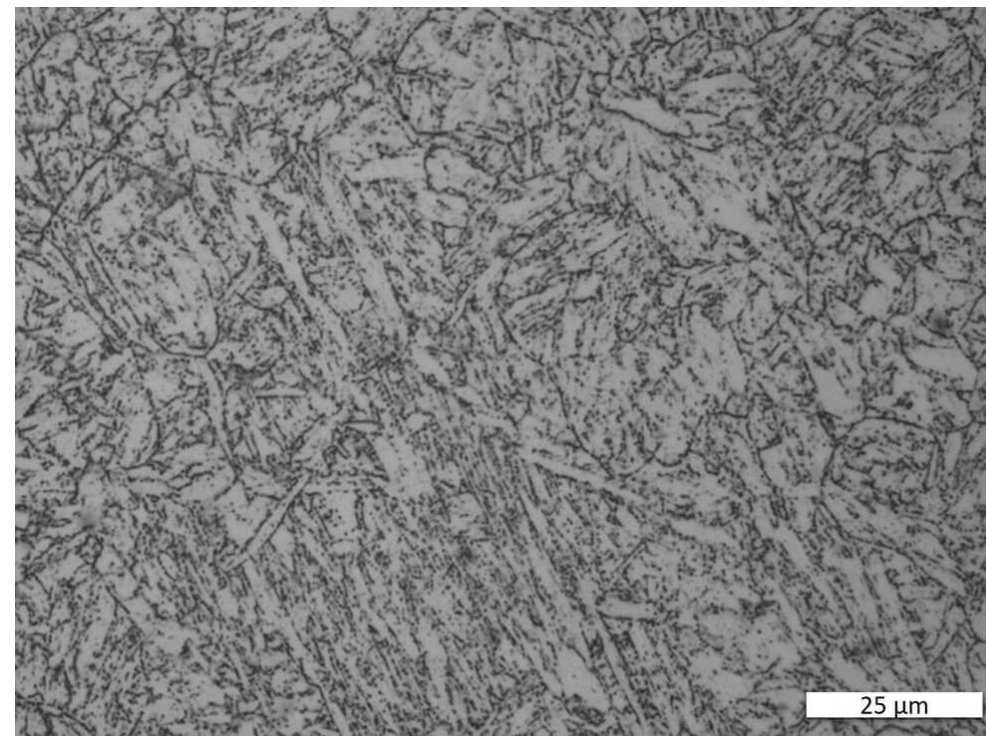

Fig. 5. Martensitic stainless steel microstructure (https://www.struers.com)

\section{DUCTILE TO BRITTLE TRANSITION TEMPERATURE}

When engineers are designing a product, the choice of material used becomes a significant consideration. The materials' fracture rate must be slowed to avoid unexpected failures. A reminder of the fracture types may be necessary for future investigations of the ductile-brittle transition temperature. Metal fractures can be divided into ductile and brittle fractures, each with distinct propagation mechanisms and energy capabilities[3]. During the progression of a ductile fracture, a significant quantity of energy is consumed. Since ductile materials have higher toughness than brittle materials, the energy required for ductile materials to fail is usually more effective than the energy required for brittle materials to fail. As a result, failure propagation in brittle materials is faster than in ductile materials.

Furthermore, a significant amount of plastic deformation can be seen during the deformation of ductile materials. Plastic deformation of ductile metals is critical because a change in the metal's shape can be interpreted as a warning sign that the metal will collapse. Plastic deformation of brittle metals, on the other hand, is barely visible due to the metals' quick brittle fracture and low energy expenditure during failure. As a result, for most applications, ductile fractures are preferred for detecting and controlling potential failures.

Furthermore, the temperature at which a material's behavior shifts from ductile to brittle or vice versa is critical for product design. The temperature at which a material transitions from ductile to brittle or brittle to ductile is called the 'Ductile to Brittle Transition Temperature (DBTT). Other definitions are used as well: DBTT is the temperature in the middle of the upper and lower shelf energy, or the temperature for a $50 \%$ crystalline fracture surface, or the temperature for a specific lateral extension, and so on.

The ductile to brittle transition temperature is strongly dependant on the composition of the metal. Steel is the most commonly used metal that shows this behavior. Throughout history, many cases have occurred where catastrophic failures have occurred due to brittle fracture [1921]. The Titanic's sinking is the most renowned of these. The brittleness of the steel used to create the Titanic's hull was the main reason for the ship's sinking. The steel was below the ductile to brittle transition temperature in the cold waters of the Atlantic. In these conditions, even a minor collision may have resulted in significant harm. The bolts that held the steel plates together brittlely fractured due to an iceberg's impact on the ship's hull. In terms of martensite 
stainless steel, many authors reported that the DBTT of martensite stainless steel is $0-50^{\circ} \mathrm{C}$. The utilization of martensite stainless steel in this temperature should be considered due to DBTT temperature.

Generally, the Impact method was used to assess a material's DBTT at various temperatures. The impact energy for general representation is plotted against temperature, as shown in Fig. 6. Tempered martensitic steels, such as AISI 403, have low room temperature fracture toughness and a DBTT close to ambient [22]. The room temperature fracture toughness and impact toughness values of tempered martensitic steel were significantly improved by a homogenous distribution of fine-sized carbides precipitates with a reduced aspect ratio.

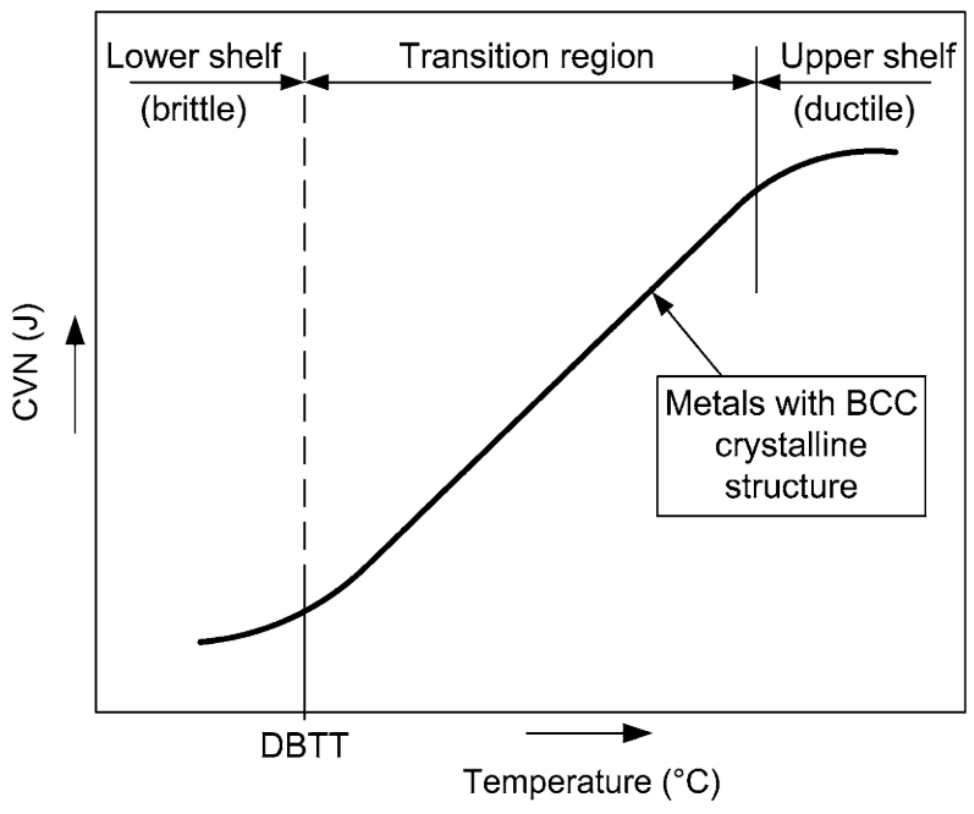

Fig. 6. The impact energy as a function of temperature

The $\mathrm{Cr}$ content in martensite stainless steel significantly affects mechanical properties such as creep strength, corrosion resistance, oxidation resistance, and the ductile-brittle transition temperature (DBTT) [14, 23-25]. In terms of fabrication methods like hot rolling, the direction of crack propagation substantially impacts DBTT, which is influenced by crystallographic texture and microstructural morphology; the DBTT is extremely low in the case of fracture with delamination[26]. In addition to the type and composition of the existing elements, DBTT is also influenced by the cooling path used [27-29]. Charpy impact toughness tests were performed over a wide temperature range to characterize the ductile-to-brittle transition. The maintained austenite fraction increased from 0.6 percent to 2.6 percent when the cooling rate was reduced from $300^{\circ} \mathrm{C} / \mathrm{s}$ to $3{ }^{\circ} \mathrm{C} / \mathrm{s}$, and the ductile-to-brittle transition temperature was decreased by $140{ }^{\circ} \mathrm{C}$ [28]. Fig. (a and b) shows the Charpy test of $\mathrm{Cr}$ martensitic steels. The surface of the probe, when fractured in a brittle field, the surface of the probe offers the characteristic morphological feature of quasi-cleavage fracture mode, which consists of slightly concave facets arising from individual micro-cracks, propagate through the material to coalesce. Tear ridges in the zones where metal ligaments rupture between separate microcracks, causing them to merge [30-32].

The presence of Carbon-enriched metastable retained austenite promotes ductility and, therefore, reduces the ductile-to-brittle transition temperature. Retained austenite increases the strain required to reach the critical cleavage fracture stress required to initiate cleavage 
initiation in the ductile to brittle transition area [28, 33, 34]. Transformation-induced plasticity (TRIP) behavior is an example of retained austenite contribution to hardening, formability, and fracture toughness improvement [27, 35-39]. Retained austenite (RA) on martensite stainless steel can be shown in Fig. 7.
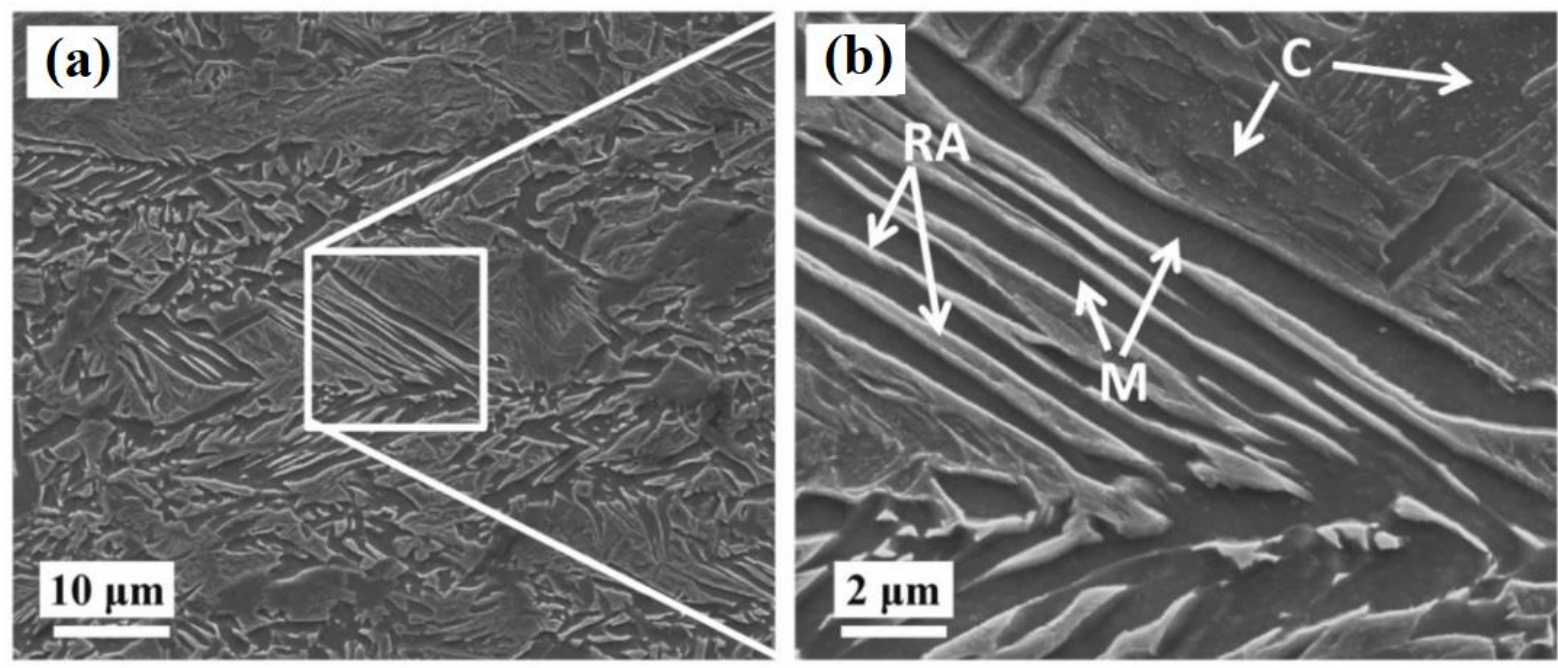

Fig. 7. Secondary electron micrographs of retained austenite; M: Martensite, RA: Retained austenite, F: Ferrite, C: Carbides) [33].

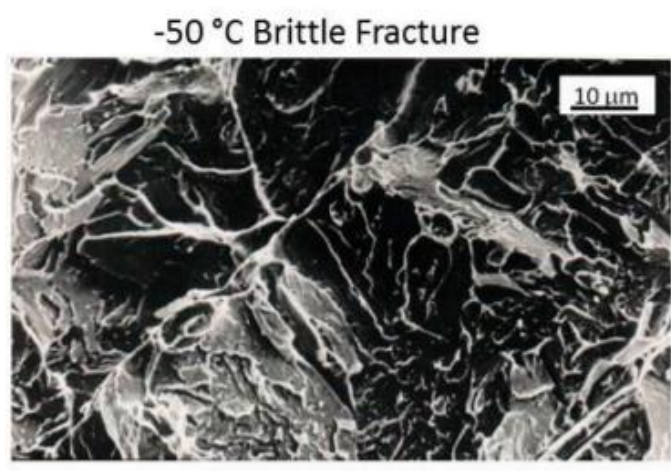

As-quenched

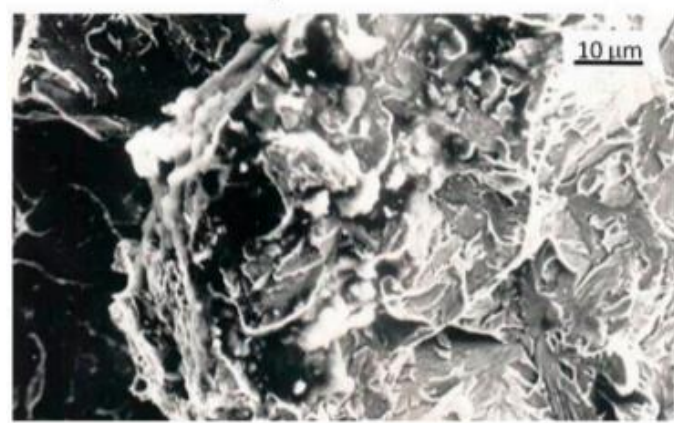

10 hours $/ 700^{\circ} \mathrm{C}$ $+100^{\circ} \mathrm{C}$ Ductile Fracture

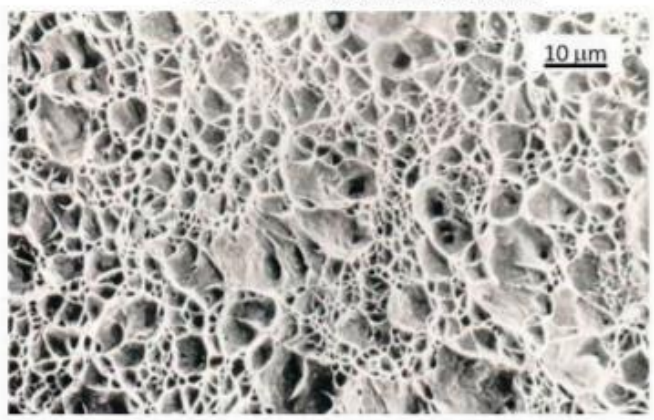

As-quenched

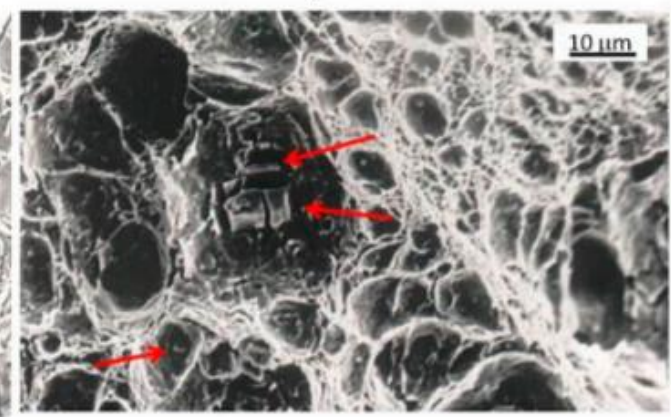

10 hours $/ 700^{\circ} \mathrm{C}$

Fig. 8. Fracture surfaces of the martensite stainless steel [14] 


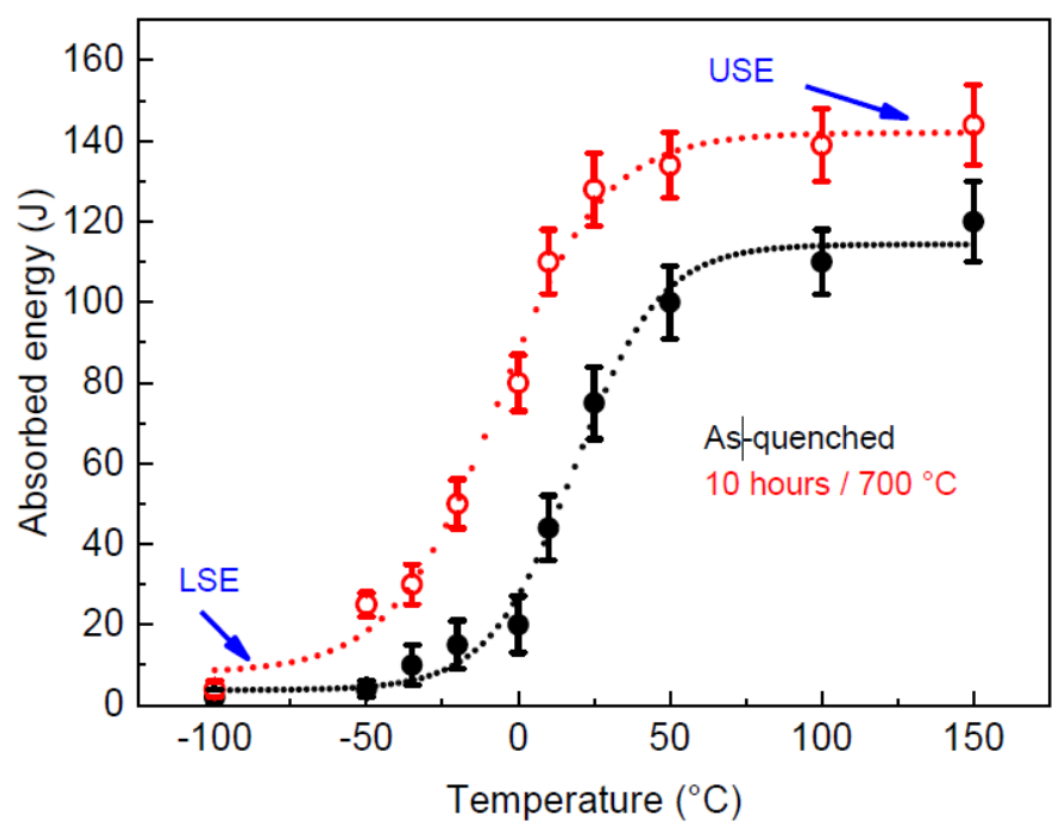

(b)

Fig. 9. The Charpy test result were performed according to UNI EN ISO 148-1 2016 standard in the temperature range from -100 to +150 . [14]

Oxidation resistance is significant for high $\mathrm{Cr}$ steels in some applications [40]. Chromium is the most effective alloying element to improve oxidation resistance. However, an increase of chromium content above $10 \%$ may result in the formation of $\delta$-ferrite, which is detrimental for creep strength and fracture toughness. As a result, the steel may become brittle and prone to cracking at room temperature, especially under dynamic loading conditions (Fig. 8-9).

\section{SUPER MARTENSITIC STAINLESS STEELS}

At the end of the 1950s, the idea of Super Martensitic Stainless Steels (SMSS) developed. $13 \%$ Cr alloyed Super Martensitic Stainless Steels (SMSS) are frequently employed as downhole tubular products in the oil and gas industry. Because of their low carbon content, these were referred to as soft martensitic stainless steels. SMSS has significantly enhanced strength, ductility, weldability, and corrosion resistance compared to typical martensitic stainless steels by lowering carbon content and increasing nickel and molybdenum content [41-43].

SMSS chemical compositions are based on the Fe-Cr-Ni-Mo system, with 4-6\% Ni, 0.5$2.5 \% \mathrm{Mo}$, low $\mathrm{C}$ content $(0.02 \%)$, and various microalloying and nitrogen content. The retained austenite that results from tempering reversed austenite is advantageous for improving ductility and toughness. While enhanced strength and acceptable toughness are achieved, pitting corrosion resistance is poor due to the presence of coarse precipitates richer in $\mathrm{Cr}$ in high angle grain boundaries, which deplete $\mathrm{Cr}$ in their vicinity below the pitting corrosion threshold [44].

\section{CONCLUSION}

Martensitic stainless steel is a type of stainless steel with high tensile strength but is brittle compared to other kinds of stainless steel. Due to their good mechanical qualities and high corrosion resistance, martensitic stainless steels are widely employed. However, the necessity 
for better characteristics in specific applications prompted extensive research into how to improve the performance of these steels.

\section{REFERENCES}

[1] M. F. McGuire, Stainless Steels for Design Engineers. ASM International, 2008.

[2] J. C. Lippold and D. J. Kotecki, Welding Metallurgy and Weldability of Stainless Steels. John Wiley \& Son, 2005.

[3] W. D. Callister and D. G. Rethwisch, Materials Science and Engineering: An Introduction, 9th Edition: Ninth Edition. John Wiley and Sons, Incorporated, 2013.

[4] G. Coates and P. Cutler. (2009) Stainless Steels. Advanced Materials \& Processes.

[5] S. Kou, Welding Metallurgy. John Wiley \& Sons, Inc, 2003.

[6] K. Morshed-Behbahani, N. Zakerin, P. Najafisayar, and M. Pakshir, "A survey on the passivity of tempered AISI 420 martensitic stainless steel," Corrosion Science, vol. 183, 2021.

[7] M. I. Ramli, A. B. Sulong, N. Muhamad, A. Muchtar, and A. Arifin, "Stainless steel 316Lhydroxyapatite composite via powder injection moulding: rheological and mechanical properties characterisation," Materials Research Innovations, vol. 18, no. S6, pp. S6-100-S6104, 2014.

[8] A. Arifin, A. B. Sulong, N. Muhamad, J. Syarif, and M. I. Ramli, "Material processing of hydroxyapatite and titanium alloy (HA/Ti) composite as implant materials using powder metallurgy: A review," (in English), Materials \& Design, vol. 55, no. 0, pp. 165-175, Mar 2014.

[9] P. J. Hidalgo, "Pitting corrosion of martensitic cutlery steels," Surface Technology, vol. 10, no. 3, pp. 193-208, 1980.

[10] S. S. M. Tavares, "Microstructure and Properties of New Super-Martensitic And Super-FerriticMartensitic Stainless Steels," in Stainless Steel Microstructure, Mechanical Properties and Methods of Application, A. Pramanik and A. K. Basak, Eds.: Nova Science Publishers, Inc, 2015.

[11] L. D. Barlow and M. Du Toit, "Effect of Austenitizing Heat Treatment on the Microstructure and Hardness of Martensitic Stainless Steel AISI 420," Journal of Materials Engineering and Performance, vol. 21, no. 7, pp. 1327-1336, 2011.

[12] N. Alonso-Falleiros, M. Magri, and I. G. S. Falleiros, "Intergranular Corrosion in a Martensitic Stainless Steel Detected by Electrochemical Tests," Corrosion Engineering Science and Technology, vol. 55, no. 8, 1999.

[13] N. Alonso-Falleiros, M. Magri, and I. G. S. Falleiros, "Intergranular Corrosion in a Martensitic Stainless Steel Detected by Electrochemical Tests," Corrosion, vol. 55, no. 8, pp. 769-778, 1999.

[14] E. Bolli et al., "Cr Segregation and Impact Fracture in a Martensitic Stainless Steel," Coatings, vol. 10, no. 9, 2020.

[15] A. Dalmau, C. Richard, and A. Igual - Muñoz, "Degradation mechanisms in martensitic stainless steels: Wear, corrosion and tribocorrosion appraisal," Tribology International, vol. 121, pp. 167-179, 2018.

[16] A. N. Isfahany, H. Saghafian, and G. Borhani, "The effect of heat treatment on mechanical properties and corrosion behavior of AISI420 martensitic stainless steel," Journal of Alloys and Compounds, vol. 509, no. 9, pp. 3931-3936, 2011.

[17] D. C. Moreira, H. C. Furtado, J. S. Buarque, B. R. Cardoso, B. Merlin, and D. D. C. Moreira, "Failure analysis of AISI 410 stainless-steel piston rod in spillway floodgate," Engineering Failure Analysis, vol. 97, pp. 506-517, 2019.

[18] R. L. Klueh, "Analysis of swelling behaviour of ferritic/martensitic steels," Philosophical Magazine, vol. 98, no. 28, pp. 2618-2636, 2018.

[19] M. D. Harris et al., "Revisiting (Some of) the Lasting Impacts of the Liberty Ships via a Metallurgical Analysis of Rivets from the SS "John W. Brown"," Jom, vol. 67, no. 12, pp. 2965-2975, 2015.

[20] K. Kendall, "Cracks: a century of toughness," in Crack Control, 2021, pp. 1-29.

[21] J. Lancaster, "The technical background," in Engineering Catastrophes, 2005, pp. 139-189. 
[22] J. S. Dubey, S. L. Wadekar, and J. K. Chakravartty, "Elevated temperature fracture toughness of AISI 403 martensitic stainless steel," Journal of Nuclear Materials, vol. 254, no. 2-3, pp. 271-274, 1998.

[23] V. Dudko, J. Borisova, and R. Kaibyshev, "Ductile-Brittle Transition in Martensitic 12\%Cr Steel," Acta Physica Polonica A, vol. 134, no. 3, pp. 649-652, 2018.

[24] B.Sunil Kumar, VivekanandKain, and V. B, "Effect of Tempering Treatments on Microstructure and Intergranular Corrosion of 13wt\% Cr Martensitic Stainless Steel," CORROSION, pp. 362-378, 2017.

[25] V. Dudko, A. Belyakov, and R. Kaibyshev, "Evolution of Lath Substructure and Internal Stresses in a 9\% Cr Steel during Creep," ISIJ International, vol. 57, no. 3, pp. 540-549, 2017.

[26] O. Takahashi, Y. Shibui, P. G. Xu, S. Harjo, T. Suzuki, and Y. Tomota, "Microstructural Features and Ductile-Brittle Transition Behavior in Hot-Rolled Lean Duplex Stainless Steels," Quantum Beam Science, vol. 4, no. 1, 2020.

[27] J. Chen, W.-n. Zhang, Z.-y. Liu, and G.-d. Wang, "The Role of Retained Austenite on the Mechanical Properties of a Low Carbon 3Mn-1.5Ni Steel," Metallurgical and Materials Transactions A, vol. 48, no. 12, pp. 5849-5859, 2017.

[28] H. Godin, J.-D. Mithieux, C. Parrens, G. Badinier, M. Sennour, and A.-F. Gourgues-Lorenzon, "Effects of cooling path and resulting microstructure on the impact toughness of a hot stamping martensitic stainless steel," Materials Science and Engineering: A, vol. 742, pp. 597-607, 2019.

[29] Y. J. Li et al., "A novel phase transition behavior during dynamic partitioning and analysis of retained austenite in quenched and partitioned steels," Materials Science and Engineering: A, vol. 710, pp. 181-191, 2018.

[30] A. J. Cooper, N. I. Cooper, A. Bell, J. Dhers, and A. H. Sherry, "A Microstructural Study on the Observed Differences in Charpy Impact Behavior Between Hot Isostatically Pressed and Forged 304L and 316L Austenitic Stainless Steel," Metallurgical and Materials Transactions $A$, vol. 46, no. 11, pp. 5126-5138, 2015.

[31] S. S. M. Tavares, H. F. Abreu, T. R. Strohaecker, M. B. Silva, and M. C. S. d. Macêdo, "Influence of Heat Treatments on the Impact Toughness of a Ti-stabilized $12 \% \mathrm{Cr}$ Supermartensitic Stainless Steel," Materials Research, vol. 20, no. 2, pp. 469-473, 2017.

[32] M. Mirzaee, A. Momeni, N. Aieni, and H. Keshmiri, "Effect of quenching and tempering on microstructure and mechanical properties of 410 and $410 \mathrm{Ni}$ martensitic stainless steels," Journal of Materials Research, vol. 32, no. 3, pp. 687-696, 2017.

[33] G. K. Bansal, V. Rajinikanth, C. Ghosh, V. C. Srivastava, M. Dutta, and S. Ghosh Chowdhury, "Effect of cooling rate on the evolution of microstructure and mechanical properties of nonisothermally partitioned steels," Materials Science and Engineering: A, vol. 788, 2020.

[34] K. Zhang, M. Zhang, Z. Guo, N. Chen, and Y. Rong, "A new effect of retained austenite on ductility enhancement in high-strength quenching-partitioning-tempering martensitic steel," Materials Science and Engineering: A, vol. 528, no. 29-30, pp. 8486-8491, 2011.

[35] M. K. El-Fawkhry, M. Eissa, A. Fathy, and T. Mattar, "Development of Maraging Steel with Retained Austenite in Martensite Matrix," Materials Today: Proceedings, vol. 2, pp. S711S714, 2015.

[36] L. Kučerová, H. Jirková, and B. Mašek, "Continuous Cooling of CMnSi TRIP Steel," Materials Today: Proceedings, vol. 2, pp. S677-S680, 2015.

[37] B. Fu, W. Y. Yang, M. Y. Lu, Q. Feng, L. F. Li, and Z. Q. Sun, "Microstructure and mechanical properties of $\mathrm{C}-\mathrm{Mn}-\mathrm{Al}-\mathrm{Si}$ hot-rolled TRIP steels with and without $\mathrm{Nb}$ based on dynamic transformation," Materials Science and Engineering: A, vol. 536, pp. 265-268, 2012.

[38] J. Hu et al., "Ensuring combination of strength, ductility and toughness in medium-manganese steel through optimization of nano-scale metastable austenite," Materials Characterization, vol. 136, pp. 20-28, 2018.

[39] Z. J. Xie, S. F. Yuan, W. H. Zhou, J. R. Yang, H. Guo, and C. J. Shang, "Stabilization of retained austenite by the two-step intercritical heat treatment and its effect on the toughness of a low alloyed steel," Materials \& Design, vol. 59, pp. 193-198, 2014. 
[40] M. S. Anwar, S. A. Chandra, R. N. Hakim, S. Prifiharni, Miftah, and E. Mabruri, "Hightemperature Oxidation Resistance of Martensitic Stainless Steel 13Cr3Mo3Ni-cast after Heat Treated," Materials Today: Proceedings, vol. 13, pp. 235-240, 2019.

[41] X. P. Ma, L. J. Wang, C. M. Liu, and S. V. Subramanian, "Role of Nb in low interstitial $13 \mathrm{Cr}$ super martensitic stainless steel," Materials Science and Engineering: A, vol. 528, no. 22-23, pp. 6812-6818, 2011.

[42] D. Ye, J. Li, W. Jiang, J. Su, and K. Zhao, "Effect of $\mathrm{Cu}$ addition on microstructure and mechanical properties of $15 \%$ Cr super martensitic stainless steel," Materials \& Design, vol. 41, pp. 16-22, 2012.

[43] A. Bojack, L. Zhao, P. F. Morris, and J. Sietsma, "In-situ determination of austenite and martensite formation in 13Cr6Ni2Mo supermartensitic stainless steel," Materials Characterization, vol. 71, pp. 77-86, 2012.

[44] X. P. Ma, L. J. Wang, C. M. Liu, and S. V. Subramanian, "Microstructure and properties of 13Cr5Ni1Mo0.025Nb0.09V0.06N super martensitic stainless steel," Materials Science and Engineering: A, vol. 539, pp. 271-279, 2012. 